\title{
Correction: Incident CTS in a large pooled cohort study: associations obtained by a Job Exposure Matrix versus associations obtained from observed exposures
}

Dale AM, Ekenga CC, Buckner-Petty S, et al. Incident CTS in a large pooled cohort study: associations obtained by a Job Exposure Matrix versus associations obtained from observed exposures. Occup Environ Med 2018;75:501-6.

There are incorrect values reported in the results section, and in tables 2 and 3 of this paper. The corrected values are slight and do not affect the implications of the results in the study. Below are the specific corrections to the text as well as the corrected tables.

\section{DISTRIBUTION OF PHYSICAL EXPOSURES}

Table 2 shows the distribution of time-weighted exposures among study participants. The median for the $\mathrm{O}$ *NET-derived strength variables indicated modest levels of job requirement for dynamic strength (median $=2.12$; Interquartile range $(\mathrm{IQR})=0.37$ on a $0-7$ point scale) with an anchor of "use pruning shears to trim a bush" and static strength (median $=2.50$; $\mathrm{IQR}=0.50$ on a $0-7$ point scale) with a score of 1 meaning "push an empty shopping cart" and 4 meaning "pull a 40-pound [18.2 kg] sack of fertilizer across the lawn." The median value for time spent making repetitive motions was 4.14 (IQR $=1.07$ on a $0-5$ point scale), equivalent to "more than half of the time". The median value for handling and moving objects was similar to "load boxes on an assembly line" (median $=5.47 ; \mathrm{IQR}=0.50$ on a 0-7 point scale), and the median value for time spent using your hands to handle, control, or feel objects was 4.66 (IQR $=0.70$ on a $1-5$ point scale).

Peak force values for the individually observed values were measured on the Borg scale (median=3.00 on a $0-10$ point scale). Observed repetition was assessed by the HAL (median=4.94 on a 0-10 point scale). Forceful exertion was measured by the \% forceful exertions (median=19.83) and Repetitions/Min of forceful exertions (median=5.00).

\section{PHYSICAL EXPOSURES AND INCIDENT CTS}

Hazard ratios (HRs), 95\% CIs, and standard errors (SE) for incident CTS are shown in table 3. For both JEM derived and observed exposures variables, continuous models showed statistically meaningful associations for all exposure variables except for observed Hand Activity Level (HAL). Dichotomous models showed HR in the range of 1.2-1.78 when using JEM exposure variables, and 1.28-1.74 when using individually observed values. The JEM variables of static strength and time spent using hands to handle and control objects did not attain statistical significance, nor did the observed values of HAL and repetitions per minute of forceful exertion. Models using tertiles of exposure showed dose effects between the upper and middle tertiles for most exposure variables. HR for the highest vs. the lowest tertile of exposure ranged from 1.30 to 1.81 for JEM exposures and 1.32-2.10 for observed values.

Table 2 Distribution of time-weighted exposures by assessment method

\begin{tabular}{|c|c|c|c|c|c|c|c|c|}
\hline Type & $\begin{array}{l}\text { Assessment } \\
\text { method }\end{array}$ & Exposure & Scale & Min & Q1 & Median* & Q3 & Max \\
\hline \multirow[t]{3}{*}{ Force intensity } & Observed & Observer peak Borg & $0-10$ & 0.00 & 1.75 & 3.00 & 4.00 & 10.00 \\
\hline & O*NET & Dynamic strength & $0-7$ & 0.00 & 1.75 & 2.12 & 2.12 & 3.00 \\
\hline & O*NET & Static strength & $0-7$ & 0.00 & 2.50 & 2.50 & 3.00 & 3.88 \\
\hline \multirow[t]{3}{*}{ HAL repetition rate } & Observed & Observer HAL & $0-10$ & 0.00 & 4.00 & 4.94 & 6.00 & 10.00 \\
\hline & O*NET & $\begin{array}{l}\text { Time spent making } \\
\text { repetitive motions }\end{array}$ & $0-5$ & 1.79 & 3.67 & 4.14 & 4.74 & 4.87 \\
\hline & O*NET & $\begin{array}{l}\text { Time spent using your } \\
\text { hands to handle, control, or } \\
\text { feel objects }\end{array}$ & $1-5$ & 1.70 & 4.21 & 4.66 & 4.91 & 4.96 \\
\hline \multirow[t]{3}{*}{ Forceful exertions } & Observed & $\%$ forceful exertions & $0-100$ & 0.00 & 6.30 & 19.83 & 37.96 & 100.00 \\
\hline & Observed & Reps/Min forceful exertions & cont & 0.00 & 1.40 & 5.00 & 12.80 & 95.72 \\
\hline & O*NET & $\begin{array}{l}\text { Handling and moving } \\
\text { objects }\end{array}$ & $0-7$ & 0.15 & 4.97 & 5.47 & 5.47 & 6.42 \\
\hline
\end{tabular}


Table 3 Hazard Ratios* (HRs), and 95\% CI for incident carpal tunnel syndrome

\begin{tabular}{|c|c|c|c|c|c|c|}
\hline \multirow[b]{3}{*}{ Type } & \multirow[b]{3}{*}{$\begin{array}{l}\text { Assessment } \\
\text { method }\end{array}$} & \multirow[b]{3}{*}{ Exposure } & \multicolumn{4}{|l|}{ HR (95\% Cl) } \\
\hline & & & \multirow{2}{*}{$\begin{array}{l}\begin{array}{l}\text { Continuous } \\
\text { exposure }\end{array} \\
\text { Per 1-unit } \\
\text { increase }\end{array}$} & \multirow{2}{*}{$\begin{array}{l}\begin{array}{l}\text { Dichotomous } \\
\text { exposuret }\end{array} \\
\text { (High vs Low) } \\
\end{array}$} & \multicolumn{2}{|c|}{ Trichotomous exposure $\ddagger$} \\
\hline & & & & & (High vs Low) & $\begin{array}{l}\text { (Medium vs } \\
\text { Low) }\end{array}$ \\
\hline \multirow[t]{3}{*}{ Force intensity } & Observed & Observer peak Borg & $\begin{array}{l}1.16(1.09 \text { to } \\
1.25)\end{array}$ & $\begin{array}{l}1.38(1.06 \text { to } \\
1.80)\end{array}$ & $\begin{array}{l}2.10(1.47 \text { to } \\
3.00)\end{array}$ & $\begin{array}{l}1.75(1.30 \text { to } \\
2.35)\end{array}$ \\
\hline & O*NET & Dynamic strength & $\begin{array}{l}1.60(1.28 \text { to } \\
1.99)\end{array}$ & $\begin{array}{l}1.64(1.20 \text { to } \\
2.24)\end{array}$ & $\begin{array}{l}1.71(1.05 \text { to } \\
2.78)\end{array}$ & $\begin{array}{l}1.53(1.05 \text { to } \\
2.23)\end{array}$ \\
\hline & O*NET & Static strength & $\begin{array}{l}1.38 \\
(1.17, \text { to } 1.63)\end{array}$ & $\begin{array}{l}1.20 \text { (0.78 to } \\
1.83)\end{array}$ & $\begin{array}{l}1.30 \text { (0.87 to } \\
1.94)\end{array}$ & $\begin{array}{l}1.29(0.77 \text { to } \\
2.15)\end{array}$ \\
\hline \multirow[t]{3}{*}{ Repetition } & Observed & Observer HAL & $\begin{array}{l}1.08 \\
(0.96, \text { to } 1.22)\end{array}$ & $\begin{array}{l}1.28(0.90 \text { to } \\
1.83)\end{array}$ & $\begin{array}{l}1.32(0.88 \text { to } \\
2.00)\end{array}$ & $\begin{array}{l}1.42(0.96 \text { to } \\
2.11)\end{array}$ \\
\hline & O*NET & $\begin{array}{l}\text { Time spent making } \\
\text { repetitive motions }\end{array}$ & $\begin{array}{l}1.58(1.24 \text { to } \\
2.00)\end{array}$ & $\begin{array}{l}1.42(1.02 \text { to } \\
1.97)\end{array}$ & $\begin{array}{l}1.62(1.12 \text { to } \\
2.36)\end{array}$ & $\begin{array}{l}1.30(0.84 \text { to } \\
2.01)\end{array}$ \\
\hline & O*NET & $\begin{array}{l}\text { Time spent using } \\
\text { your hands to handle } \\
\text { to control, or feel } \\
\text { objects }\end{array}$ & $\begin{array}{l}1.78(1.41 \text { to } \\
2.24)\end{array}$ & $\begin{array}{l}1.36(0.99 \text { to } \\
1.87)\end{array}$ & $\begin{array}{l}1.81(1.24 \text { to } \\
2.64)\end{array}$ & $\begin{array}{l}1.51 \text { (1.06 to } \\
2.13)\end{array}$ \\
\hline \multirow{3}{*}{$\begin{array}{l}\text { Forceful } \\
\text { exertions } \\
\text { (duration/rate) }\end{array}$} & Observed & $\begin{array}{l}\% \text { duration forceful } \\
\text { exertions }\end{array}$ & $\begin{array}{l}1.01(1.01 \text { to } \\
1.02)\end{array}$ & $\begin{array}{l}1.74(1.38 \text { to } \\
2.20)\end{array}$ & $\begin{array}{l}1.80(1.33 \text { to } \\
2.43)\end{array}$ & $\begin{array}{l}1.47(1.12 \text { to } \\
1.93)\end{array}$ \\
\hline & Observed & $\begin{array}{l}\text { Reps/Min forceful } \\
\text { exertions }\end{array}$ & $\begin{array}{l}1.02(1.01 \text { to } \\
1.02)\end{array}$ & $\begin{array}{l}1.38(0.98 \text { to } \\
1.95)\end{array}$ & $\begin{array}{l}1.90(1.31 \text { to } \\
2.75)\end{array}$ & $\begin{array}{l}1.15(0.75 \text { to } \\
1.77)\end{array}$ \\
\hline & O*NET & $\begin{array}{l}\text { Handling and moving } \\
\text { objects }\end{array}$ & $\begin{array}{l}1.29(1.13 \text { to } \\
1.48)\end{array}$ & $\begin{array}{l}1.78 \text { (1.37 to } \\
2.31)\end{array}$ & $\begin{array}{l}1.70(1.17 \text { to } \\
2.46)\end{array}$ & $\begin{array}{l}1.85(1.38 \text { to } \\
2.50)\end{array}$ \\
\hline
\end{tabular}

*Cox proportional hazard regression models with robust sandwich estimators, adjusted for age, gender, body mass index, and study site.

tExposures are dichotomized at the median.

\#Exposures are trichotomized at 33rd and 67th percentiles.

JEM, Job Exposure Matrix; O*NET, Occupational Network; HAL, Hand activity level; LL, lower limit; UL, upper limit.

\section{6 \\ OPEN ACCESS}

Open access This is an open access article distributed in accordance with the Creative Commons Attribution Non Commercial (CC BY-NC 4.0) license, which permits others to distribute, remix, adapt, build upon this work noncommercially, and license their derivative works on different terms, provided the original work is properly cited, appropriate credit is given, any changes made indicated, and the use is non-commercial. See: http://creativecommons.org/licenses/by-ncl 4.0\%.

(C) Author(s) (or their employer(s)) 2018. Re-use permitted under CC BY-NC. No commercial re-use. See rights and permissions. Published by BMJ.

Occup Environ Med 2018;75:761-762. doi:10.1136/oemed-2017-104744corr1

Check for updates 